\title{
Application of Te-Based Glass in Silicon Solar Cells
}

\author{
Xin-Xin Pi $\cdot$ Xiu-Hua Cao $\cdot$ Zhen-Xiao Fu $\cdot$ Le Zhang $\cdot$ Peng-De Han $\cdot$ Li-Xi Wang $\cdot$ Qi-Tu Zhang
}

Received: 23 November 2013/Revised: 9 May 2014/Published online: 31 December 2014

(C) The Chinese Society for Metals and Springer-Verlag Berlin Heidelberg 2014

\begin{abstract}
TeO}_{2}-x \mathrm{ZnO}-10 \mathrm{Bi}_{2} \mathrm{O}_{3}\left(x=15,17.5,20\right.$ and 22.5, in mol\%) and $70 \mathrm{TeO}_{2}-20 \mathrm{ZnO}-(10-y) \mathrm{Bi}_{2} \mathrm{O}_{3}-y$ $\mathrm{Na}_{2} \mathrm{O}(y=1,3,5,7$, and 10, in mol\%) glasses, and the corresponding $\mathrm{Ag}$ paste were prepared in order to prove that the Te-based glass frit could be applied to $\mathrm{Ag}$ pastes to fabricate $\mathrm{Ag}$ electrode. The relationship between structure and properties of the glasses was analyzed. The effects of glass frit on the microstructure, adhesion force, and resistivity of the $\mathrm{Ag}$ electrode were studied. The microstructure of $\mathrm{Ag}$ electrodes and the phase analysis of interface between $\mathrm{Ag}$ electrodes and the $\mathrm{Si}$ wafer were investigated using SEM and XRD. Finally, the $70 \mathrm{TeO}_{2}-20 \mathrm{ZnO}-5 \mathrm{Bi}_{2} \mathrm{O}_{3}-5 \mathrm{Na}_{2} \mathrm{O}$ glass showed better performance in the paste. What is more, Ag crystallites could be found on the $\mathrm{Si}$ wafer. These results suggested that the Te-based glass frit could react with $\mathrm{SiN}_{x}$ anti-reflecting coating and $\mathrm{Si}$ to serve as a medium for forming Ag crystallites.
\end{abstract}

KEY WORDS: Solar cells; Ag electrode; Silver paste; Tellurite glass; Ag crystallites

\section{Introduction}

In the preparation of single-crystalline or polycrystalline $\mathrm{Si}$ solar cells, Ag electrode is formed on the front side with a $\mathrm{SiN}_{x}$ anti-reflecting coating (ARC) for stable ohmic contact. The Ag electrode is commonly fabricated by screenprinting using silver paste which consists of $\mathrm{Ag}$ powder, glass frit, and organic vehicle [1-3]. Although as an inorganic binder, glass frit only holds $2 \%-5 \%$ in mass, it plays a crucial role in the front-side metallization contact

Available online at http://link.springer.com/journal/40195

X.-X. Pi · L. Zhang · P.-D. Han · L.-X. Wang ·

Q.-T. Zhang $(\bowtie)$

College of Materials Science and Engineering,

Nanjing University of Technology, Nanjing 210009, China

e-mail: zhqt@njtech.edu.cn

X.-H. Cao - Z.-X. Fu

Guangdong Fenghua Advanced Technology Company Limited,

Zhaoqing 526000, China formation and achieving current paths between $\mathrm{Ag}$ electrode and $\mathrm{Si}$ wafer. Through etching the $\mathrm{SiN}_{x}$ coating and allowing the formation of $\mathrm{Ag}$ crystallites grown into the silicon emitter during the firing process, glass frit not only determines the adhesion strength of $\mathrm{Ag}$ electrode to $\mathrm{Si}$ wafer, but also determines the final resistance of the electrode $[4,5]$. In general, a dense population of fine $\mathrm{Ag}$ crystallites at the $\mathrm{Ag}-\mathrm{Si}$ interface is desirable for improving the quality of the ohmic contacts with the Si emitters $[6,7]$. Therefore, it is necessary to choose the appropriate glass system and gain more insight into the mechanism for Ag crystallite formation.

At present, the industrial glass frit for front-side silver paste is almost $\mathrm{Pb}$-based glass which has excellent electrical and mechanical properties. Schubert et al. [8] proposed a growth model of $\mathrm{Ag}$ crystallites in the $\mathrm{PbO}$ containing $\mathrm{Ag}$ paste, which has been the basic understanding of the $\mathrm{Ag}$ electrode formation mechanism. However, since lead exposure and pollution are detrimental to human health and environment, it is necessary to take more emphases on the research and application of 
the lead-free silver paste. In previous studies, the use of Bi-based glass frit in Ag paste has been reported [9, 10]. Kim et al. [11] reported that $\mathrm{Bi}_{2} \mathrm{O}_{3}$ can participate in the reactions with $\mathrm{SiN}_{x}$ coating or $\mathrm{Si}$ wafer, which serves as a seed for the $\mathrm{Ag}$ dissolved in the glass to crystallization. Che et al. [12] prepared the $\mathrm{Bi}-\mathrm{Si}-\mathrm{B}-\mathrm{Al}-\mathrm{Zn}-\mathrm{O}$ glass frit with glass transition temperature of $385{ }^{\circ} \mathrm{C}$ by traditional melting rout. The wetting behavior and etching effect of glass frit on $\mathrm{SiN}_{x} \mathrm{ARC}$ and silicon were efficient. While the thermal and mechanical properties of Bi-based glass frit are still needed to be optimized. The tellurite glass has been widely used for optical applications [13]. It has a stable performance and a low glass transition temperature which would be a potential material for Ag paste [14]. For example, Vitreous domain phase diagram for the $\mathrm{TeO}_{2}-$ $\mathrm{Bi}_{2} \mathrm{O}_{3}-\mathrm{ZnO}$ system has been given by Massera et al. and the glasses were used in optical applications [15]. However, Te-based glass frit as an inorganic binder for $\mathrm{Ag}$ electrodes in Si solar cells has not been studied so far. And there has been no experiment conducted to investigate how Te-based glass frit affects contact formation between $\mathrm{Ag}$ and $\mathrm{Si}$.

In this paper, $(90-x) \mathrm{TeO}_{2}-x \mathrm{ZnO}-10 \mathrm{Bi}_{2} \mathrm{O}_{3}$ glasses were prepared according to the vitreous domain phase diagram and the $\mathrm{Na}_{2} \mathrm{O}$ was added to decrease the glass transition temperature. Finally, the $70 \mathrm{TeO}_{2}-20 \mathrm{ZnO}-(10-y) \mathrm{Bi}_{2} \mathrm{O}_{3}-$ $y \mathrm{Na}_{2} \mathrm{O}$ glasses were used in $\mathrm{Ag}$ pastes. The relationship between structure and properties of the glass was analyzed. The effect of glass frit on the microstructure, adhesion force, and resistivity of the Ag electrode was investigated. And the phases of crystallites formed on the Si wafer were studied. Overall, the aim of these experiments is to verify that the as-prepared eco-friendly Te-based glass system could be applied to Ag pastes.

\section{Experimental}

The glass frit was prepared by traditional melting route at 800-850 ${ }^{\circ} \mathrm{C}$ for $20 \mathrm{~min}$ in an alumina crucible, the reagent grade $\mathrm{TeO}_{2}, \mathrm{ZnO}, \mathrm{Bi}_{2} \mathrm{O}_{3}$, and $\mathrm{Na}_{2} \mathrm{O}$ were employed as raw materials. The glass transition temperature $\left(T_{\mathrm{g}}\right)$ and crystallization temperature $\left(T_{\mathrm{c}}\right)$ were determined using a differential scanning calorimeter (DSC, NETZSCH, STA449F3) at the heating rate of $10{ }^{\circ} \mathrm{C} \min ^{-1}$. The glass softening temperature $\left(T_{\mathrm{f}}\right)$ and thermal expansion coefficient $(\alpha)$ were measured by a thermo-analyzer (TMA, SETARAM, TMA-16/18). The chemical durability of the glasses was evaluated by dissolution rate (DR) in distilled water at $90{ }^{\circ} \mathrm{C}$ for $24 \mathrm{~h}$. The crystal structures of the prepared glass frit was investigated by XRD with $\mathrm{Cu} K_{\alpha}$ radiation $(\lambda=1.5406 \AA)$. The infrared spectra were recorded with an FTIR spectrometer (Nicolet NEXU
S670). The Raman spectra were obtained with a Raman spectrometer (Labram HR, $\lambda=514 \mathrm{~nm}$ ).

The Ag paste consisted of $67 \mathrm{wt} \% \mathrm{Ag}$ power, $3 \mathrm{wt} \%$ glass frit, and $30 \mathrm{wt} \%$ organic vehicle. The organic vehicle consisted of ethylcellulose, terpilenol, and few additives. The formulated paste was screen-printed through a nylon mesh on Si substrates with $\mathrm{SiN}_{x}$ coating. After oven drying at $190{ }^{\circ} \mathrm{C}$ for $10 \mathrm{~min}$, the printed paste was fired in a tube furnace at $800{ }^{\circ} \mathrm{C}$ for $10 \mathrm{~min}$ to obtain the $\mathrm{Ag}$ electrode. The surface and cross-sectional microstructures of the electrode were investigated by SEM (Philips, XL30). The adhesion force and resistivity of electrode were measured by peel force tester and resistivity tester of four-point probe technique. When the $\mathrm{Ag}$ bulk and glass layers were removed selectively using $\mathrm{HNO}_{3}$ and $\mathrm{HF}$ solutions, the phases of crystallites formed on the $\mathrm{Si}$ wafer were examined using XRD. Tables 1 and 2 present the physicochemical properties of the $(90-x) \mathrm{TeO}_{2}-x \mathrm{ZnO}-10 \mathrm{Bi}_{2} \mathrm{O}_{3}$ and $70 \mathrm{TeO}_{2}-20 \mathrm{ZnO}-(10-y) \mathrm{Bi}_{2} \mathrm{O}_{3}-y \mathrm{Na}_{2} \mathrm{O}$ glass and the adhesion force and resistivity of the corresponding $\mathrm{Ag}$ electrodes, respectively.

\section{Results and Discussion}

\subsection{Structures and Properties of $(90-x) \mathrm{TeO}_{2}-x \mathrm{ZnO}-$ $10 \mathrm{Bi}_{2} \mathrm{O}_{3}$ Glasses}

The infrared spectra of the $(90-x) \mathrm{TeO}_{2}-x \mathrm{ZnO}-10 \mathrm{Bi}_{2} \mathrm{O}_{3}$ glasses are given in Fig. 1, where $x$ is 15, 17.5, 20 and $22.5 \mathrm{~mol} \%$. The broad band at $655 \mathrm{~cm}^{-1}$ belongs to the stretching vibration of axial Te-O bonds $\left(\mathrm{Te}-\mathrm{O}_{\mathrm{ax}}\right)$ in the $\mathrm{TeO}_{4}$ tbp [16]. The band at $740-757 \mathrm{~cm}^{-1}$ could be ascribed to the stretching vibration of equatorial Te-O bonds $\left(\mathrm{Te}-\mathrm{O}_{\text {eq }}\right)$ in the $\mathrm{TeO}_{3}$ tp, which moves to higher frequency a little when $\mathrm{ZnO}$ content in the glass is from 15 to $22.5 \mathrm{wt} \%$ [13]. It indicates that some $\mathrm{TeO}_{4}$ tbp structure units are transformed into $\mathrm{TeO}_{3}$ tp, which weakens the network structure of tellurite glass. Thus, the changes of properties shown in the Table 1 can be explained reasonably. As the $\mathrm{ZnO}$ content in the glass increases, the chemical durability and glass softening temperature decrease, while the thermal expansion coefficient increases, which is attributed to the weakening of the network structure.

Figure 2 shows DTA curves of the $(90-x) \mathrm{TeO}_{2}-x \mathrm{ZnO}-$ $10 \mathrm{Bi}_{2} \mathrm{O}_{3}$ glasses. When $x$ is $15,17.5$, and 22.5 , the corresponding glasses have two crystallization peaks. However, when $x=20$, there is only one crystallization peak. The data of crystallization temperature can be seen in Table 1 . The thermal stability is represented by temperature difference $\left(\Delta T=T_{\mathrm{c} 1}-T_{\mathrm{g}}\right)$. The greater the temperature difference, the better the thermal stability is. Since $\Delta T$ appears 
Table 1 Physicochemical properties of the $(90-x) \mathrm{TeO}_{2}-x \mathrm{ZnO}-10 \mathrm{Bi}_{2} \mathrm{O}_{3}$ glass

\begin{tabular}{llllllll}
\hline Sample & $T_{\mathrm{g}}\left({ }^{\circ} \mathrm{C}\right)$ & $T_{\mathrm{c} 1}\left({ }^{\circ} \mathrm{C}\right)$ & $T_{\mathrm{c} 2}\left({ }^{\circ} \mathrm{C}\right)$ & $\Delta T\left({ }^{\circ} \mathrm{C}\right)$ & $T_{\mathrm{f}}\left({ }^{\circ} \mathrm{C}\right)$ & $\alpha\left(10^{-6} /{ }^{\circ} \mathrm{C}\right)$ & $\mathrm{DR}\left(\mathrm{g} \mathrm{cm}{ }^{-2} \mathrm{~min}^{-1}\right)$ \\
\hline$x=15$ & 371 & 448 & 566 & 77 & 654 & 9 & $4.0621 \times 10^{-8}$ \\
$x=17.5$ & 377 & 470 & 570 & 97 & 615 & 11 & $4.1458 \times 10^{-8}$ \\
$x=20$ & 384 & 561 & N/A & 177 & 610 & 12 & $4.2592 \times 10^{-8}$ \\
$x=22.5$ & 368 & 476 & 578 & 103 & 593 & 15 & $4.3605 \times 10^{-8}$ \\
\hline
\end{tabular}

Table 2 Physicochemical properties of the $70 \mathrm{TeO}_{2}-20 \mathrm{ZnO}-(10-y) \mathrm{Bi}_{2} \mathrm{O}_{3}-y \mathrm{Na}_{2} \mathrm{O}$ glasses and the adhesion force and resistivity of the corresponding $\mathrm{Ag}$ electrodes

\begin{tabular}{lllrllllll}
\hline Sample & $T_{\mathrm{g}}\left({ }^{\circ} \mathrm{C}\right)$ & $T_{\mathrm{c} 1}\left({ }^{\circ} \mathrm{C}\right)$ & $\Delta T\left({ }^{\circ} \mathrm{C}\right)$ & $T_{\mathrm{f}}\left({ }^{\circ} \mathrm{C}\right)$ & $\alpha\left(10^{-6} /{ }^{\circ} \mathrm{C}\right)$ & $\mathrm{DR}\left(\mathrm{g} \mathrm{cm}^{-2} \mathrm{~min}^{-1}\right)$ & $\begin{array}{l}\text { Ag electrode } \\
\text { code }\end{array}$ & $\begin{array}{l}\text { Adhesion } \\
\text { force }(\mathrm{N})\end{array}$ & $\begin{array}{l}\text { Resistivity } \\
(\mu \Omega \mathrm{cm})\end{array}$ \\
\hline$y=1$ & 375 & 475 & 100 & 573 & 13 & $1.3678 \times 10^{-7}$ & $\mathrm{ZN} 1$ & 2.1 & 2.6021 \\
$y=3$ & 366 & 465 & 99 & 540 & 15 & $2.4239 \times 10^{-7}$ & $\mathrm{ZN} 2$ & 2.7 \\
$y=5$ & 354 & 457 & 103 & 500 & 16 & $4.5617 \times 10^{-7}$ & $\mathrm{ZN} 3$ & 3.3 & 2.5378 \\
$y=7$ & 330 & 428 & 98 & 485 & 21 & $1.0648 \times 10^{-6}$ & $\mathrm{ZN} 4$ & 4.7 & 2.4124 \\
$y=10$ & 310 & 411 & 101 & 450 & 24 & $2.0216 \times 10^{-6}$ & $\mathrm{ZN} 5$ & 6.0 & 2.3569 \\
\hline
\end{tabular}

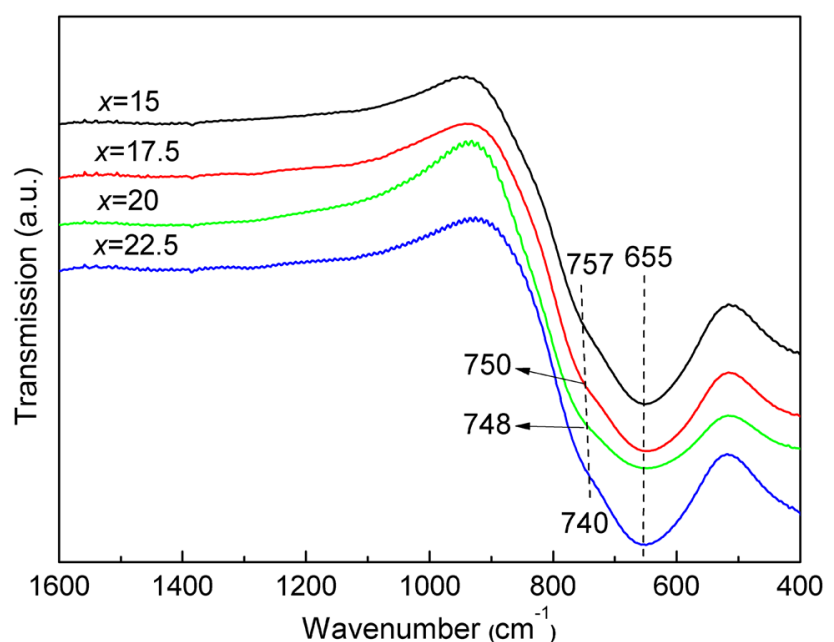

Fig. 1 Infrared spectra of $(90-x) \mathrm{TeO}_{2}-x \mathrm{ZnO}-10 \mathrm{Bi}_{2} \mathrm{O}_{3}$ glasses

maximum value at $x=20$, it shows that the thermal stability of $70 \mathrm{TeO}_{2}-20 \mathrm{ZnO}-10 \mathrm{Bi}_{2} \mathrm{O}_{3}$ glass is the best one among the as-prepared glasses.

The SEM micrographs corresponding to surface of the $\mathrm{Ag}$ electrodes and cross section between $\mathrm{Ag}$ and $\mathrm{Si}$ wafer using $70 \mathrm{TeO}_{2}-20 \mathrm{ZnO}-10 \mathrm{Bi}_{2} \mathrm{O}_{3}$ glass in the paste are displayed in Fig. 3. From Fig. 3a, it is seen that the Ag grains gathered together, which resulted in poor evolution in the $\mathrm{Si}$ wafer. What is more, the pore distribution was not uniform. In addition, clear interstices existed between the Ag electrodes and Si wafer in Fig. 3b, which indicates that the adhesion of Ag electrodes is very weak. The measured adhesion force is $1.2 \mathrm{~N}$. It is suggested that the glass softening temperature $\left(610^{\circ} \mathrm{C}\right)$ is too high to etching the

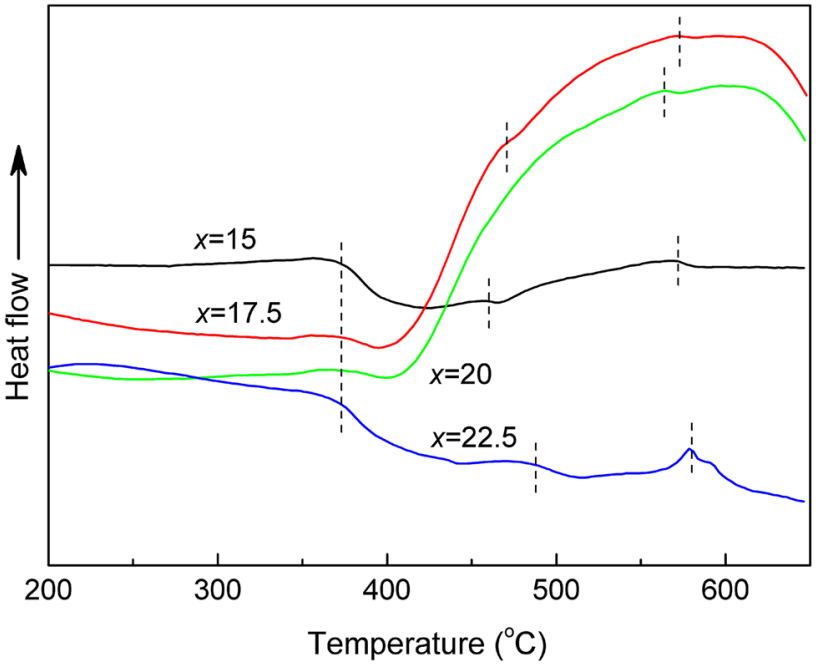

Fig. 2 DTA thermograms of the investigated glasses in the (90$x) \mathrm{TeO}_{2}-x \mathrm{ZnO}-10 \mathrm{Bi}_{2} \mathrm{O}_{3}$ (heating rate is $10{ }^{\circ} \mathrm{C} / \mathrm{min}$ )

$\mathrm{SiN}_{x}$ coating and participating in the reaction to form a thin glass layer. Therefore, it is necessary to optimize the $70 \mathrm{TeO}_{2}-20 \mathrm{ZnO}-10 \mathrm{Bi}_{2} \mathrm{O}_{3}$ glass to obtain a good comprehensive performance.

\subsection{Effect of $\mathrm{Na}_{2} \mathrm{O}$ Content on the Structures} and Properties of $70 \mathrm{TeO}_{2}-20 \mathrm{ZnO}-(10-y) \mathrm{Bi}_{2} \mathrm{O}_{3}-$ $y \mathrm{Na}_{2} \mathrm{O}$ Glasses

The $\mathrm{Na}_{2} \mathrm{O}$ with different contents $(1,3,5,7$, and $10 \mathrm{~mol} \%)$ was added to the $70 \mathrm{TeO}_{2}-20 \mathrm{ZnO}-(10-y) \mathrm{Bi}_{2} \mathrm{O}_{3}-y \mathrm{Na}_{2} \mathrm{O}$ glasses. The IR spectra of the glasses are given in Fig. 4. The band at $665 \mathrm{~cm}^{-1}$ and $755-773 \mathrm{~cm}^{-1}$ are attributed to 

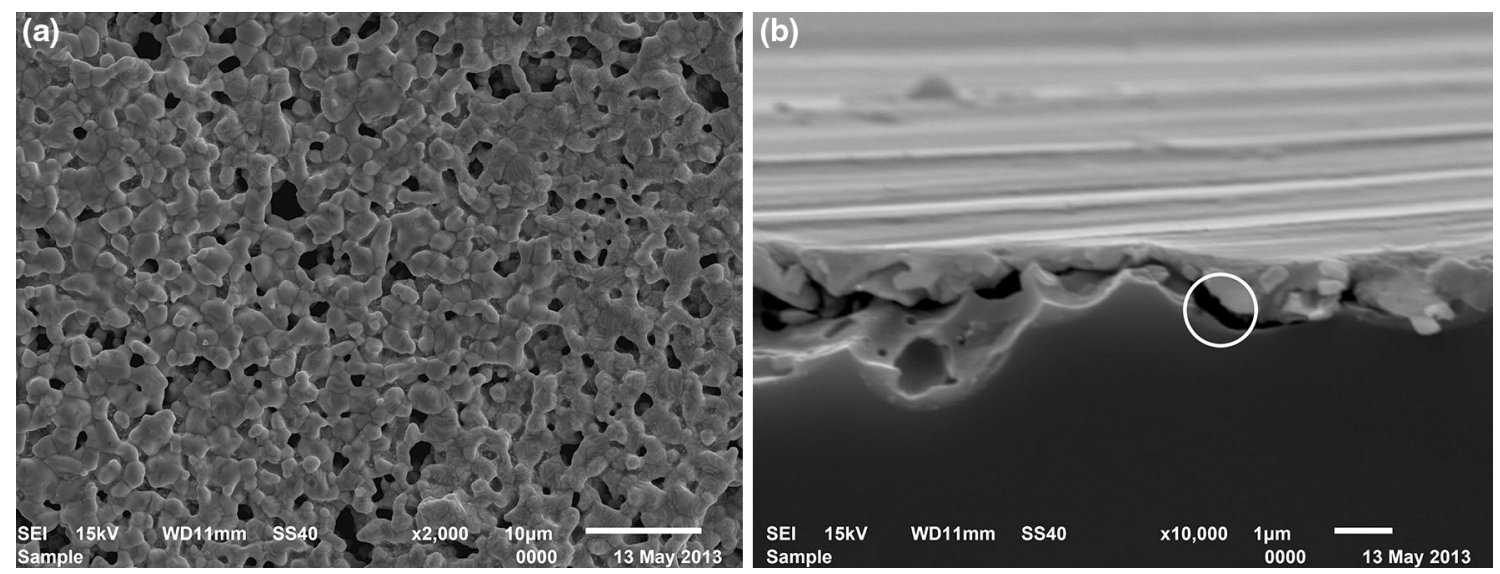

Fig. 3 SEM images of the surface of the Ag electrode $\mathbf{a}$, cross section between Ag electrode and $\mathrm{Si}$ wafer $\mathbf{b}$, corresponding to the paste using $70 \mathrm{TeO}_{2}-20 \mathrm{ZnO}-10 \mathrm{Bi}_{2} \mathrm{O}_{3}$ glass

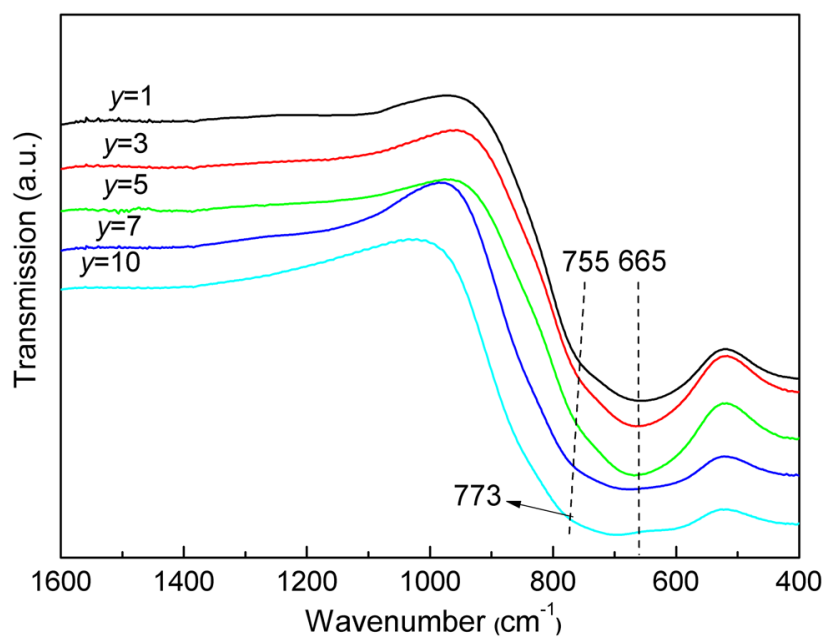

Fig. 4 Infrared spectra of the $70 \mathrm{TeO}_{2}-20 \mathrm{ZnO}-(10-y) \mathrm{Bi}_{2} \mathrm{O}_{3}-y \mathrm{Na}_{2} \mathrm{O}$ glasses

$\mathrm{TeO}_{4}$ tpb and $\mathrm{TeO}_{3}$ tp, respectively. It can be seen that the intensity of bands at $665 \mathrm{~cm}^{-1}$ decreases and the position of bands at $755-773 \mathrm{~cm}^{-1}$ shifts to lower frequencies with the increasing of $\mathrm{Na}_{2} \mathrm{O}$ content, which indicates that both of the $\mathrm{TeO}_{4}$ tpb and $\mathrm{TeO}_{3}$ tp structure units are decreasing.

The corresponding Raman spectra of $70 \mathrm{TeO}_{2}-20 \mathrm{ZnO}$ $(10-y) \mathrm{Bi}_{2} \mathrm{O}_{3}-y \mathrm{Na}_{2} \mathrm{O}$ glasses are given in Fig. 5 when $x$ is 1,5 , and $10 \mathrm{~mol} \%$. Three major Raman absorption bands are observed. The band at $401-437 \mathrm{~cm}^{-1}$ is due to the stretching of the $\mathrm{Te}-\mathrm{O}-\mathrm{Te}$ or $\mathrm{O}-\mathrm{Te}-\mathrm{O}$ bonds [17]. The band at $657-674 \mathrm{~cm}^{-1}$ belongs to the stretching vibration of $\mathrm{Te}-\mathrm{O}_{\mathrm{ax}}$ in the $\mathrm{TeO}_{4}$ tbp, while the band at $744-759 \mathrm{~cm}^{-1}$ can be ascribed to the stretching vibration of $\mathrm{Te}-\mathrm{O}$ in the $\mathrm{TeO}_{3}$ tp [18-20]. The positions of those bands both shift to lower frequencies with the increase of $\mathrm{Na}_{2} \mathrm{O}$ content. These results are consistent with the analysis of infrared spectra. Therefore, it is suggested that the $\mathrm{Na}_{2} \mathrm{O}$

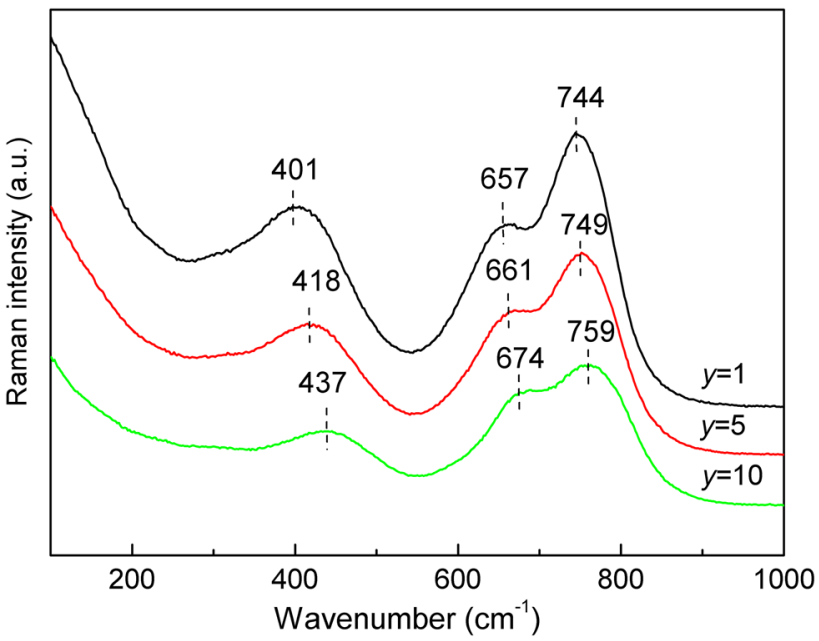

Fig. 5 Raman spectra of the $70 \mathrm{TeO}_{2}-20 \mathrm{ZnO}-(10-y) \mathrm{Bi}_{2} \mathrm{O}_{3}-y \mathrm{Na}_{2} \mathrm{O}$ glasses

is the network modifying oxide and the glass network would be increasingly depolymerized as the $\mathrm{Na}_{2} \mathrm{O}$ content increases.

The properties of $70 \mathrm{TeO}_{2}-20 \mathrm{ZnO}-(10-y) \mathrm{Bi}_{2} \mathrm{O}_{3}-y \mathrm{Na}_{2} \mathrm{O}$ glasses are given in Table 2. Figure 6 shows the dependence of the values of glass transition temperature, softening temperature, and thermal expansion coefficient on the content of $\mathrm{Na}_{2} \mathrm{O}$ in the $70 \mathrm{TeO}_{2}-20 \mathrm{ZnO}-(10-y) \mathrm{Bi}_{2} \mathrm{O}_{3}-$ $y \mathrm{Na}_{2} \mathrm{O}$ glass. It is seen that the glass transition temperature and softening temperature decrease with increasing $\mathrm{Na}_{2} \mathrm{O}$ content, whereas the values of thermal expansion coefficient increases. These results are in good agreement with the weakening of structural network, which are observed by IR spectra and Raman spectra. The chemical durability of the studied glasses is shown in Fig. 7. The DR increases exponentially with the amount of $\mathrm{Na}_{2} \mathrm{O}$ doping, which means $\mathrm{Na}_{2} \mathrm{O}$ doping can greatly decrease the chemical 


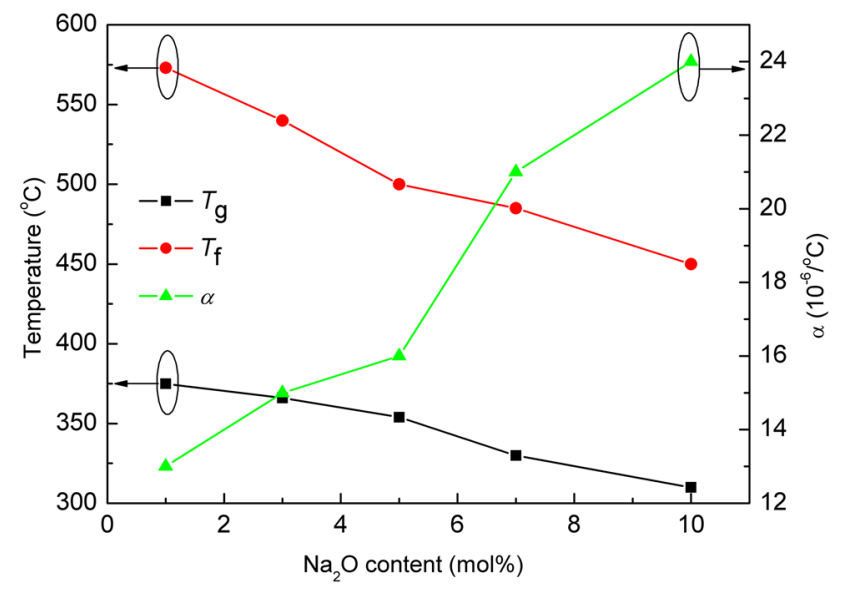

Fig. 6 Variation of the glass transition temperature, softening temperature, and thermal expansion coefficient with the $\mathrm{Na}_{2} \mathrm{O}$ content of $70 \mathrm{TeO}_{2}-20 \mathrm{ZnO}-(10-y) \mathrm{Bi}_{2} \mathrm{O}_{3}-y \mathrm{Na}_{2} \mathrm{O}$ glasses

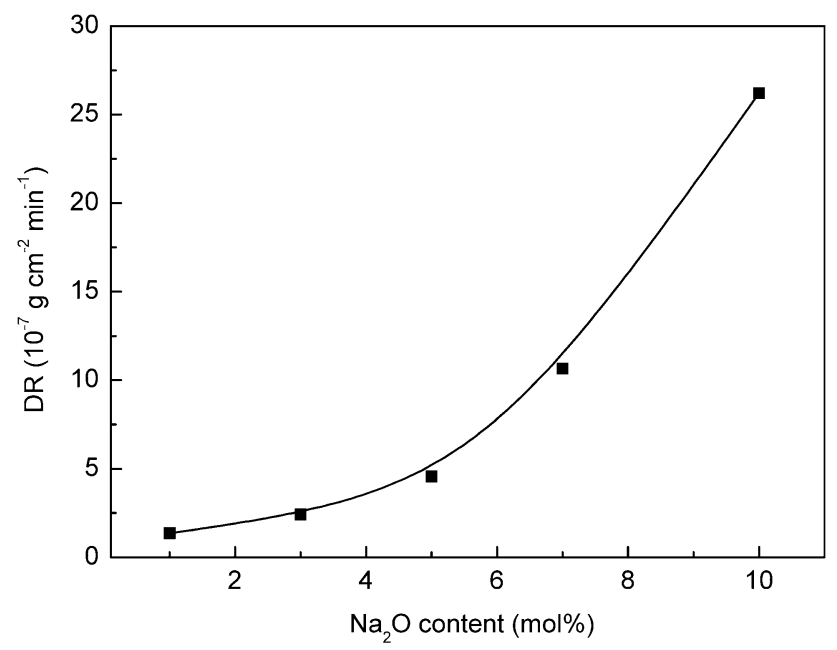

Fig. 7 Variation of the dissolution rate with the $\mathrm{Na}_{2} \mathrm{O}$ content of $70 \mathrm{TeO}_{2}-20 \mathrm{ZnO}-(10-y) \mathrm{Bi}_{2} \mathrm{O}_{3}-y \mathrm{Na}_{2} \mathrm{O}$ glasses

durability of the as-prepared glasses. This could be mainly attributed to the continuous ion exchange between the network modifying $\mathrm{Na}^{+}$in the glass and $\mathrm{H}^{+}$in the water. Only when the amount of $\mathrm{Na}_{2} \mathrm{O}$ is $5 \mathrm{~mol} \%$, the values of softening temperature, thermal expansion coefficient, and dissolution rate remain relatively low. It is supposed that the $70 \mathrm{TeO}_{2}-20 \mathrm{ZnO}-5 \mathrm{Bi}_{2} \mathrm{O}_{3}-5 \mathrm{Na}_{2} \mathrm{O}$ glass could be applied in the $\mathrm{Ag}$ paste with the highest potential.

\subsection{Effect of Glasses on the Microstructures and Properties of Ag Electrodes}

In order to verify the performance of $70 \mathrm{TeO}_{2}-20 \mathrm{ZnO}-$ $5 \mathrm{Bi}_{2} \mathrm{O}_{3}-5 \mathrm{Na}_{2} \mathrm{O}$ glass, the $\mathrm{ZN} 1, \mathrm{ZN} 3$, and ZN5 Ag electrodes were prepared and compared. The SEM images corresponding to surface of the $\mathrm{ZN} 1, \mathrm{ZN} 5$, and $\mathrm{ZN} 3 \mathrm{Ag}$ electrodes and cross section between $\mathrm{Ag}$ and $\mathrm{Si}$ wafer are displayed in Fig. 8.

$\mathrm{Ag}$ grains gathered together in the $\mathrm{ZN} 1$ electrode (Fig. 8a), which resulted in poor evolution and some big pores on the $\mathrm{Si}$ wafer. What is more, the connection between the Ag electrodes and $\mathrm{Si}$ wafer is just interlocking in $\mathrm{ZN1}$ (Fig. 8b), which indicates the adhesion of $\mathrm{Ag}$ electrodes is very weak. Both of these could be attributed to the higher $T_{\mathrm{f}}\left(573{ }^{\circ} \mathrm{C}\right)$ of glass in the $\mathrm{ZN} 1$ electrode.

It can be seen from Fig. $8 \mathrm{c}$ that the surface of the $\mathrm{Ag}$ electrodes has a hazy effect and the $\mathrm{Ag}$ grains gathered together, which probably related to the lower $T_{\mathrm{f}}\left(450^{\circ} \mathrm{C}\right)$ of glass. The holes and pits were appeared in the cross section between Ag electrode and Si wafer (Fig. 8d), which indicates that the glass has etched and even damaged the Si wafer. As expected, the corresponding electrode brings about better adhesion. However, the damage of Si wafer which would decrease the efficiency of Si solar cell is not expected.

The SEM image in Fig. 8e of ZN3 shows that the wettability of glass for the Ag powder is excellent since the distribution of $\mathrm{Ag}$ grains is uniform and a horizontal growth of Ag grains can be seen. From Fig. 8f, it can be seen that there were no interstices in the interface between $\mathrm{Ag}$ electrode and $\mathrm{Si}$ wafer and the interface was continuous and smooth. In ZN3, the Ag crystallites of 5-nm average grain size coated by the glass layer of about $10 \mathrm{~nm}$ thickness have generated in the interface (Fig. 8g), which was essential to stable ohmic contact.

The data pertaining to adhesion force and resistivity are given in Table 2. From the table, it is seen that the adhesion force enhances as the glass softening temperature decreases. These results are consistent with the analysis of SEM micrographs of Ag electrodes. Therefore, it is suggested that glass with appropriate glass softening temperature could wet the Ag powder and improve the adhesion effect between the Ag electrode and $\mathrm{Si}$ wafer by etching the $\mathrm{SiN}_{x}$ ARC to form a thin glass layer.

From the above, the $70 \mathrm{TeO}_{2}-20 \mathrm{ZnO}-5 \mathrm{Bi}_{2} \mathrm{O}_{3}-5 \mathrm{Na}_{2} \mathrm{O}$ glass is found to be ideal for the present $\mathrm{Ag}$ paste formulation.

\subsection{Analysis of Interface Between Ag Electrode and Si Wafer}

Figures 9a and $\mathrm{b}$ show the XRD patterns of surface after selectively removing $\mathrm{ZN} 3 \mathrm{Ag}$ electrode using $\mathrm{HNO}_{3} / \mathrm{HF}$ solution. Specifically, the wafer samples were immersed in $100 \mathrm{~mL} \mathrm{HNO} / \mathrm{HF}$ solution for $10 \mathrm{~min}$, which contains $2 \mathrm{~mL} \mathrm{HF} \mathrm{(40} \mathrm{wt \% ),} 6 \mathrm{~mL} \mathrm{HNO}_{3}(68 \mathrm{wt} \%$ ), and $92 \mathrm{~mL}$ deionized water. Figure $9 \mathrm{c}$ shows the XRD pattern of $\mathrm{Si}$ surface after removing Ag electrode without glass frit. XRD was used to detect the Ag crystallites formed on the Si wafer. 

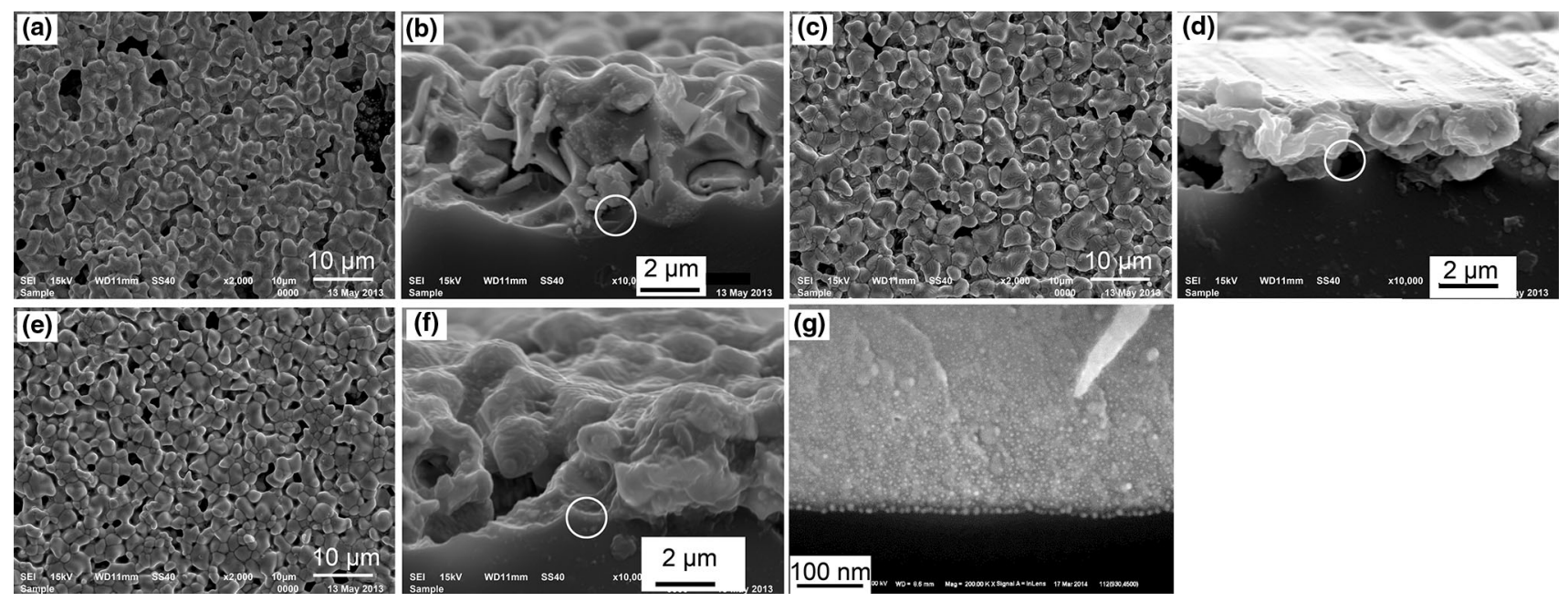

Fig. 8 SEM images of the ZN1, ZN3, and ZN5 Ag electrodes: a ZN1 surface; b ZN1 cross section; $\mathbf{c}$ ZN5 surface; $\mathbf{d}$ ZN5 cross section; e ZN3 surface; $\mathbf{f}$ ZN3 cross section; $\mathbf{g}$ ZN3 interface

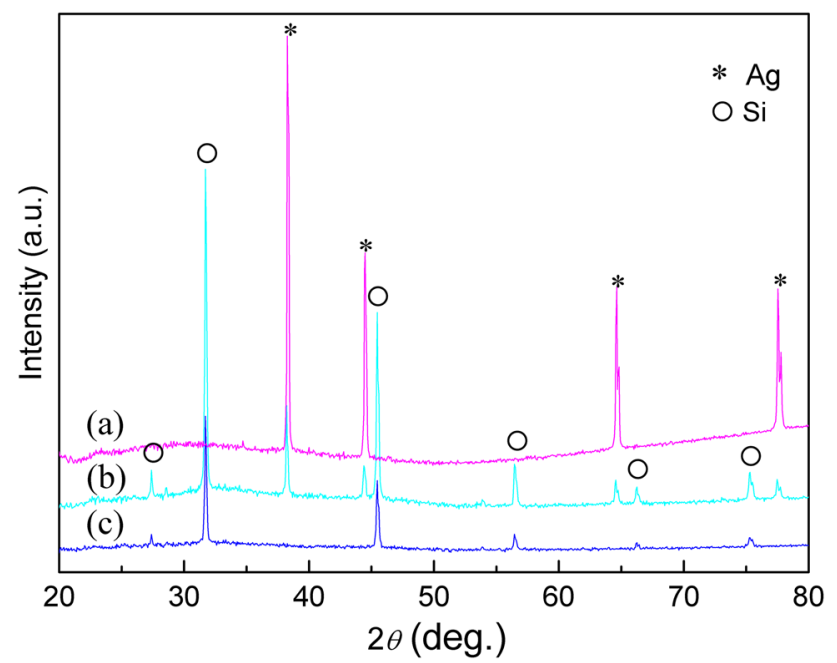

Fig. 9 XRD patterns obtained from the surface ZN3 Ag electrode a, Si surface after removing $\mathrm{ZN} 3 \mathrm{Ag}$ electrodes using $\mathrm{HNO}_{3} / \mathrm{HF}$ b, Si surface after removing $\mathrm{Ag}$ electrodes without glass frit $\mathbf{c}$

There are only diffraction peaks of Ag crystals in Fig. 9a. But the $\mathrm{Si}$ is found in both the Fig. $9 \mathrm{~b}$ and $\mathrm{c}$. However, the diffraction peaks of Ag crystals were found in the Si surface corresponding to the ZN3 Ag electrode in sharp contrast to that of $\mathrm{Ag}$ electrode without glass frit. It proves that $70 \mathrm{TeO}_{2}-20 \mathrm{ZnO}-5 \mathrm{Bi}_{2} \mathrm{O}_{3}-5 \mathrm{Na}_{2} \mathrm{O}$ glass frit plays a very important role in the process of forming $\mathrm{Ag}$ crystallites.

\section{Conclusions}

By traditional melting rout, homogeneous glasses can be prepared in the series $(90-x) \mathrm{TeO}_{2}-x \mathrm{ZnO}-10 \mathrm{Bi}_{2} \mathrm{O}_{3}$ $(x=15,17.5,20$ and $22.5 \mathrm{~mol} \%)$ and $70 \mathrm{TeO}_{2}-20 \mathrm{ZnO}-$ $(10-y) \mathrm{Bi}_{2} \mathrm{O}_{3}-y \mathrm{Na}_{2} \mathrm{O}(y=1,3,5,7$, and $10 \mathrm{~mol} \%)$. The infrared spectra and Raman spectra indicate that the based network of Te-based glasses is mainly formed by $\mathrm{TeO}_{4}$ and $\mathrm{TeO}_{3}$ units. When $x=20 \mathrm{~mol} \%$, the thermal stability of $70 \mathrm{TeO}_{2}-20 \mathrm{ZnO}-10 \mathrm{Bi}_{2} \mathrm{O}_{3}$ glass is best $\left(\Delta T=177{ }^{\circ} \mathrm{C}\right)$. However, it cannot benefit Ag electrode to integrate with $\mathrm{Si}$ wafer and offers good adhesion due to its high glass softening temperature. The $\mathrm{Na}_{2} \mathrm{O}$ with different contents was added to the $70 \mathrm{TeO}_{2}-20 \mathrm{ZnO}-(10-y) \mathrm{Bi}_{2} \mathrm{O}_{3}-y \mathrm{Na}_{2} \mathrm{O}$ glasses. $\mathrm{Na}_{2} \mathrm{O}$ acts as the network modifying oxide and the glass network would be increasingly depolymerized as its content increases. For the $70 \mathrm{TeO}_{2}-20 \mathrm{ZnO}-5 \mathrm{Bi}_{2} \mathrm{O}_{3}-5 \mathrm{Na}_{2} \mathrm{O}$ glass, the values of softening temperature, thermal expansion coefficient, and dissolution rate remain relatively low, which meets the requirements of $\mathrm{Ag}$ paste.

The $70 \mathrm{TeO}_{2}-20 \mathrm{ZnO}-5 \mathrm{Bi}_{2} \mathrm{O}_{3}-5 \mathrm{Na}_{2} \mathrm{O}$ glass could wet the $\mathrm{Ag}$ powder to form a uniform electrode and improve the adhesion effect between the Ag electrode and $\mathrm{Si}$ wafer. What is more, the Te-based glass could serve as a medium for forming Ag crystallites by etching and react with $\mathrm{SiN}_{x}$ $\mathrm{ARC}$, and $\mathrm{Si}$. Therefore, the Te-based glass could be a promising substitute for $\mathrm{Pb}$-based glass frit for preparing environmental friendly front-side $\mathrm{Ag}$ paste for crystalline silicon solar cells in the future.

Acknowledgments This work was financially supported by the Guangdong province university-industry cooperation projects (No. 2011B090400238) and Priority Academic Program Development of Jiangsu Higher Education Institutions (PAPD).

\section{References}

[1] M.M. Hilali, S. Sridharan, C. Khadilkar, A. Shaikh, A. Rohatgi, S. Kim, J. Electron. Mater. 35, 2041 (2006) 
[2] Y.N. Ko, H.Y. Koo, J.H. Kim, Y.C. Kang, J. Alloys Compd. 491, 584 (2010)

[3] A. Ebong, W. Zhang, P. Bokalo, A. Rohatgi, paper present in Proceedings of the 21st European Photovoltaic Solar Energy Conference and Exhibition, Germany, 2006, p. 4

[4] S.B. Rane, T. Seth, G.J. Phatak, D.P. Amalnerka, J. Mater. Sci.: Mater. Electron. 15, 103 (2004)

[5] Y.P. Zhang, Y.X. Yang, J.H. Zheng, G.R. Chen, C. Cheng, J.C.M. Hwang, B.S.O. Ooi, A. Kovalskiy, H. Jain, Thin Solid Films 518, 111 (2010)

[6] S.B. Cho, K.K. Hong, J.Y. Huh, H.J. Park, J.W. Jeong, Curr. Appl. Phys. 10, S222 (2010)

[7] E. Cabrera, S. Olibet, J. Glatz-Reichenbach, R. Kopecek, D. Reinke, G. Schubert, Energy Procedia 8, 540 (2011)

[8] G. Schubert, F. Huster, P. Fath, Paper present in Proceedings of the 19th EPVSEC, Paris, 2004, p. 813

[9] S.J. Jeon, S.M. Koo, S.A. Hwang, Sol. Energy Mater. Sol. Cells 93, 1103 (2009)

[10] D.S. Kim, S.J. Hwang, H.S. Kin, J. Korean Phys. Soc. 55, 1046 (2009)
[11] D. Kim, H. Kim, J. Am. Ceram. Soc. 96, 744 (2013)

[12] Q. Che, H.X. Yang, L. Lu, Y.H. Wang, J. Alloys Compd. 549, 221 (2013)

[13] L. Weng, S.N.B. Hodgson, J. Non-Cryst. Solids 297, 18 (2002)

[14] R. El-Mallawany, Tellurite Glasses Handbook: Physical Properties and Data (CRC Press, New York, 2002)

[15] J. Massera, J. Remond, J. Musgraves, M.J. Davis, S. Misture, L. Petit, K. Richardson, J. Non-Cryst. Solids 356, 2947 (2010)

[16] J. Lin, W.H. Huang, Z.R. Sun, C.S. Ray, D.E. Day, J. Non-Cryst. Solids 336, 189 (2004)

[17] B. Tincher, J. Massera, L. Petit, K. Richardson, Mater. Res. Bull. 45, 1861 (2010)

[18] V. Nazabal, S. Todoroki, A. Nukui, T. Matsumoto, S. Suehara, T. Hondo, T. Araki, S. Inoue, C. Rivero, T. Cardinal, J. NonCryst. Solids 325, 85 (2003)

[19] J. Ozdanova, H. Ticha, L. Tichy, J. Non-Cryst. Solids 355, 2318 (2009)

[20] J. Ozdanova, H. Ticha, L. Tichy, Opt. Mater. 32, 950 (2010) 